\title{
Demonstration Assessment of Light-Emitting Diode (LED) Parking Lot Lighting
}

\section{Host Site: Walmart, Leavenworth, Kansas}

Final Report prepared in support of the U.S. DOE Solid-State Lighting Technology Demonstration GATEWAY Program

Study Participants:

Pacific Northwest National Laboratory

U.S. Department of Energy

Walmart

May 2011

Prepared for the U.S. Department of Energy by

Pacific Northwest National Laboratory

\begin{tabular}{l|l} 
u.s. DEPARTMENT OF & Energy Efficiency \& \\
Renewable Energy
\end{tabular} 


\title{
DISCLAIMER
}

This report was prepared as an account of work sponsored by an agency of the United States Government. Neither the United States Government nor any agency thereof, nor Battelle Memorial Institute, nor any of their employees, makes any warranty, express or implied, or assumes any legal liability or responsibility for the accuracy, completeness, or usefulness of any information, apparatus, product, or process disclosed, or represents that its use would not infringe privately owned rights. Reference herein to any specific commercial product, process, or service by trade name, trademark, manufacturer, or otherwise does not necessarily constitute or imply its endorsement, recommendation, or favoring by the United States Government or any agency thereof, or Battelle Memorial Institute. The views and opinions of authors expressed herein do not necessarily state or reflect those of the United States Government or any agency thereof.

\author{
PACIFIC NORTHWEST NATIONAL LABORATORY \\ operated by \\ BATTELLE \\ for the \\ UNITED STATES DEPARTMENT OF ENERGY \\ under Contract DE-AC05-76RL01830
}

Printed in the United States of America

Available to DOE and DOE contractors from the

Office of Scientific and Technical Information,

P.O. Box 62, Oak Ridge, TN 37831-0062;

ph:(865) 576-8401

fax: (865) 576-5728

email: reports@adonis.osti.gov

\begin{abstract}
Available to the public from the National Technical Information Service, U.S. Department of Commerce, 5285 Port Royal Rd., Springfield, VA 22161 ph: (800) 553-6847 fax: (703) 605-6900

email: orders@ntis.fedworld.gov

online ordering: http://www.ntis.gov/ordering.htm
\end{abstract}




\section{Demonstration Assessment of Light-Emitting Diode (LED) Parking Lot Lighting in Leavenworth, KS}

Final Report prepared in support of the U.S. DOE GATEWAY Solid-State Lighting Technology Demonstration Program

Study Participants:

Pacific Northwest National Laboratory U.S. Department of Energy

Walmart

M.A. Myer

B.R. Kinzey

K.J. Curry

May 2011

Prepared for the U.S. Department of Energy under Contract DE-AC05-76RL01830 


\section{Preface}

This document is a report of observations and results obtained from a lighting demonstration project conducted under the U.S. Department of Energy (DOE) GATEWAY Solid-State Lighting Demonstration Program. The program supports demonstrations of high-performance solid-state lighting (SSL) products in order to develop empirical data and experience with in-the-field applications of this advanced lighting technology. The DOE GATEWAY Demonstration Program focuses on providing a source of independent, third-party data for use in decision-making by lighting users and professionals; this data should be considered in combination with other information relevant to the particular site and application under examination. Each GATEWAY Demonstration compares SSL products against the incumbent technologies used in that location. Depending on available information and circumstances, the SSL product may also be compared to alternate lighting technologies. Though products demonstrated in the GATEWAY program have been prescreened, DOE does not endorse any commercial product or in any way guarantee that users will achieve the same results through use of these products. 


\section{Summary}

This report describes the process and results of a demonstration of solid-state lighting (SSL) technology in a commercial parking lot lighting application, under the U.S. Department of Energy (DOE) Solid-State Lighting Technology GATEWAY Demonstration Program. The parking lot is for customers and employees of a Walmart Supercenter in Leavenworth, Kansas and this installation represents the first use of the LED Parking Lot Performance Specification developed by the DOE's Commercial Building Energy Alliance.

The application is a parking lot covering more than a half million square feet, lighted primarily by light-emitting diodes (LEDs). Metal halide wall packs were installed along the building facade. This site is new construction, so the installed baseline(s) were hypothetical designs. It was acknowledged early on that deviating from Walmart's typical design would reduce the illuminance on the site. Walmart primarily uses $1000 \mathrm{~W}$ pulse-start metal halide (PMH) lamps. In order to provide a comparison between both typical design and a design using conventional luminaires providing a lower illuminance, a 400W PMH design was also considered.

As mentioned already, the illuminance would be reduced by shifting from the PMH system to the LED system. The Illuminating Engineering Society of North America (IES) provides recommended minimum illuminance values for parking lots. All designs exceeded the recommended illuminance values in IES RP-20, some by a wider margin than others.

Energy savings from installing the LED system compared to the different PMH systems varied. Compared to the 1000W PMH system, the LED system would save 63 percent of the energy. However, this corresponds to a 68 percent reduction in illuminance as well. In comparison to the $400 \mathrm{~W} \mathrm{PMH}$ system, the LED system would save 44 percent of the energy and provide similar minimum illuminance values at the time of relamping.

The LED system cost more than either of the PMH systems when comparing initial costs. However, when the life-cycle costs from energy and maintenance were factored into the scenario, the LED system had lower costs at the end of a 10-year analysis period. The LED system had a 6.1 year payback compared to the 1000W PMH system and a 7.5 year payback versus the 400W PMH system. The costs reflect high initial cost for the LED luminaire, plus more luminaires and (subsequently) more poles for the LED system. The other major issue affecting cost effectiveness was that Leavenworth, Kansas has very low electricity costs. The melded rate for this site was $\$ 0.056$ per $\mathrm{kWh}$ for electricity. However, if the national electricity rate of $\$ 0.1022 / \mathrm{kWh}$ was used the payback would change to between four and five years for the LED system.

This demonstration met the GATEWAY requirements of saving energy, matching or improving illumination, and being cost effective. The project also demonstrated that the Commercial Building Energy Alliance (CBEA) specification works in practice. Walmart appreciated having an entire site lighted by LEDs to gain more experience with the technology. Walmart is reviewing the results of the demonstration as they consider their entire real estate portfolio. 


\section{Acronyms and Abbreviations}

AFG

ASHRAE

ANSI

BLCC

BUG

CBEA

DOE

EIA

fc

HID

IES

K

$\mathrm{kWh}$

LCC

LCS

LED

LLF

LPD

LSI

$\operatorname{lm} / \mathrm{W}$

$\mathrm{MH}$

MWh

PMH

REA

SSL

W above finished grade

American Society of Heating, Refrigerating and Air-Conditioning Engineers

American National Standards Institute

Building Life-Cycle Cost (software)

backlight, uplight, and glare

Commercial Building Energy Alliance

U.S. Department of Energy

Energy Information Administration

footcandle(s)

high-intensity discharge

Illuminating Engineering Society of North America

kelvin

kilowatt-hour(s)

life-cycle cost

Luminaire Classification System

light-emitting diode

light loss factor

lighting power density

LSI Industries, Inc.

lumen(s) per watt

metal halide

megawatt-hour(s)

pulse-start metal halide

Retailer Energy Alliance

solid-state lighting

watt(s) 


\section{Contents}

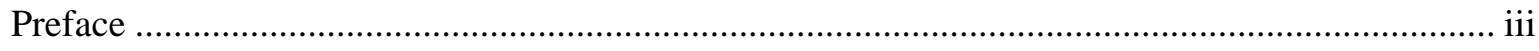

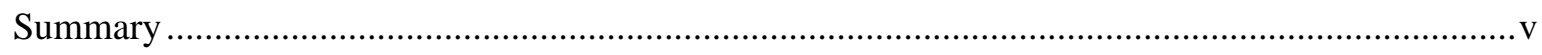

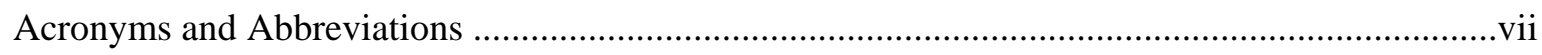

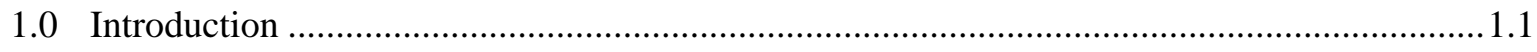

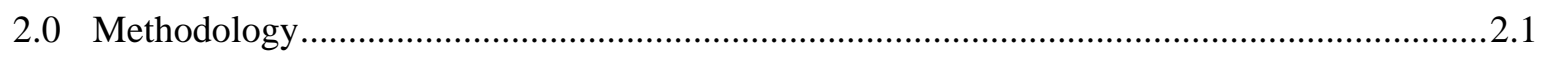

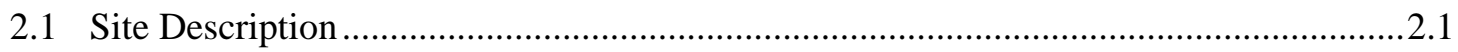

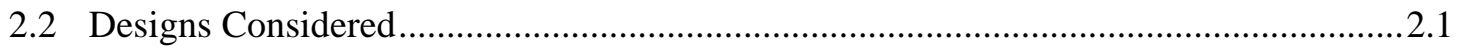

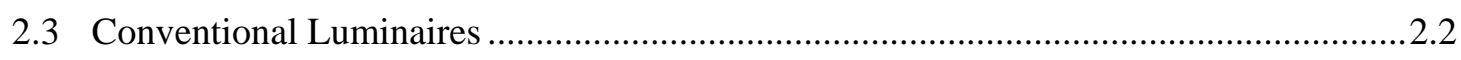

2.3.1 “Typical Design” - 1000W Luminaires ….......................................................2.2

2.3.2 Optional PMH Design - 400W Luminaires ........................................................2.3

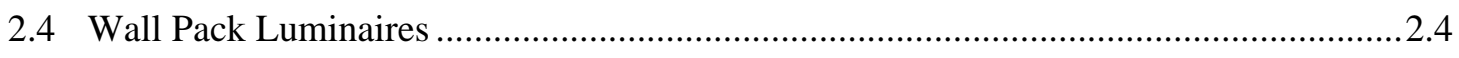

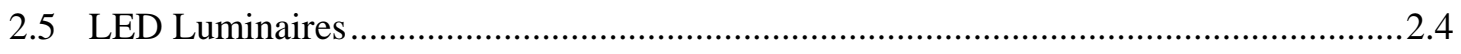

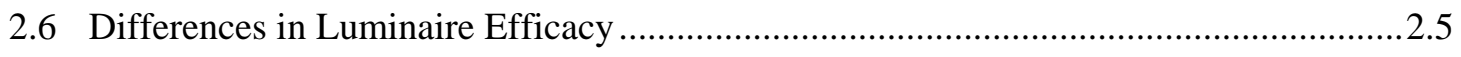

2.6.1 Conventional Component Efficiencies............................................................ 2.5

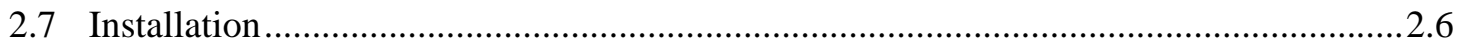

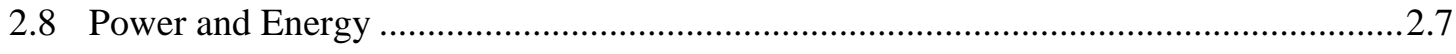

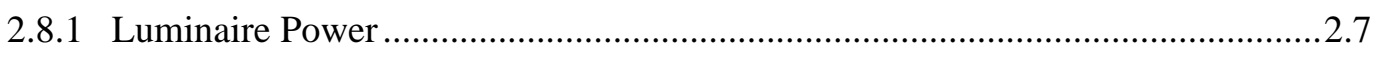

2.8.2 Operating Hours …................................................................................... 2.7

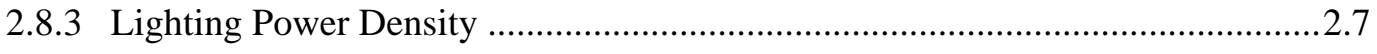

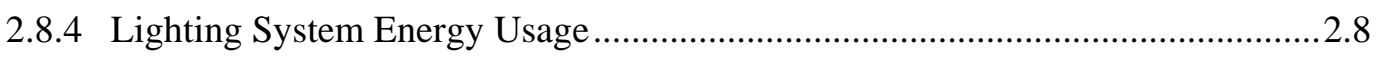

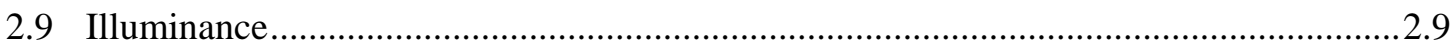

2.9.1 Designed/Calculated Values............................................................................. 2.9

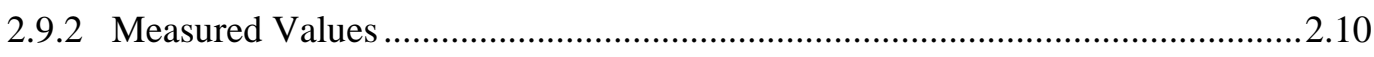

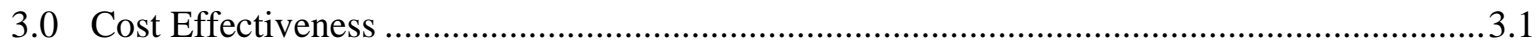

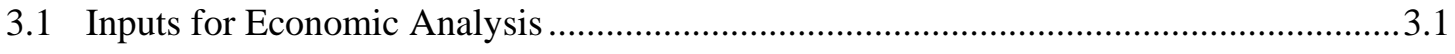

3.1.1 Cost of Equipment..................................................................................... 3.1

3.1.2 Cost of Electricity....................................................................................... 3.2

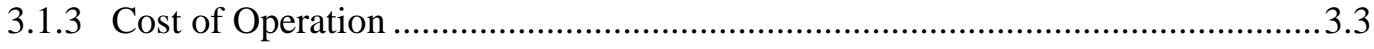

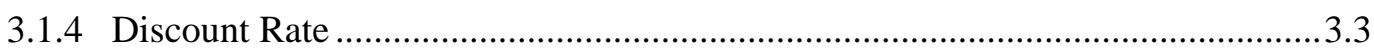

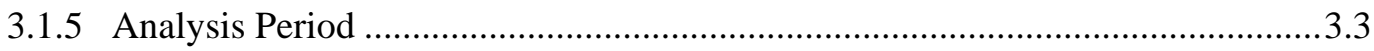

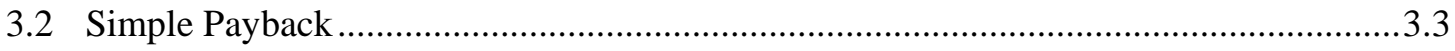

3.3 Net Present Value and Life-Cycle Cost Analysis ......................................................... 3.4

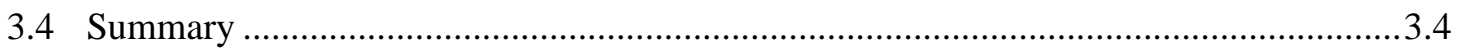

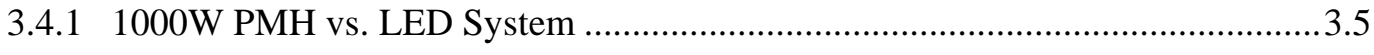

3.4.2 400W PMH System vs. LED System ............................................................... 3.5

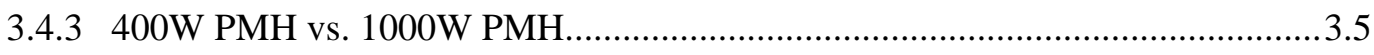




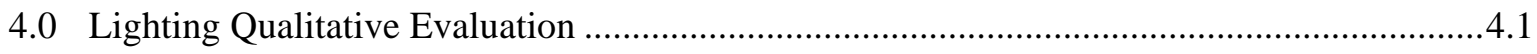

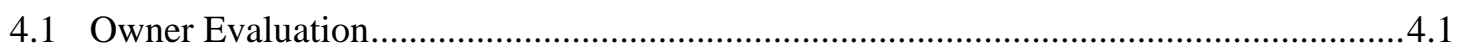

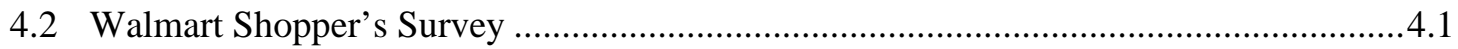

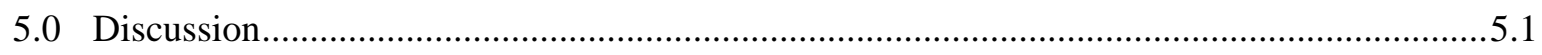

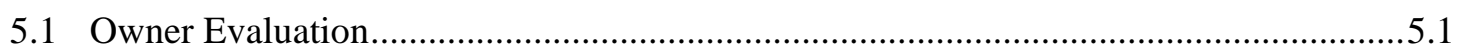

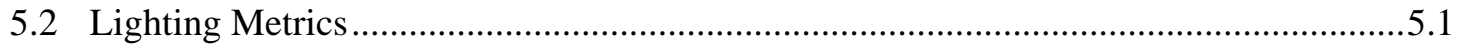

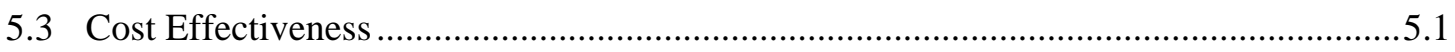

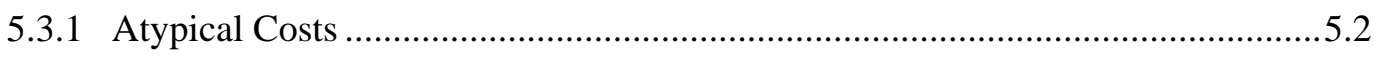

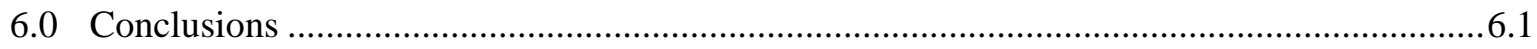

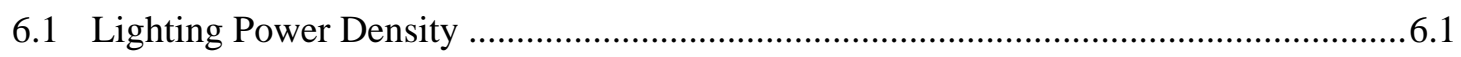

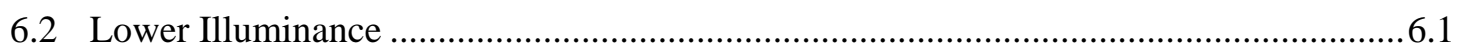

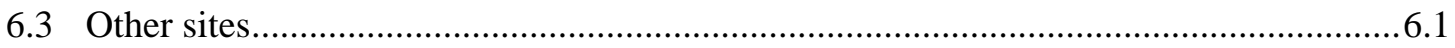

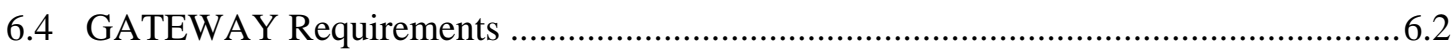

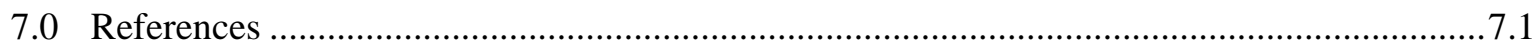




\section{Figures}

Figure 2.1. LSI Type V Distribution for 1000W Luminaire.................................................................. 2.3

Figure 2.2. LSI Type II Distribution for 1000W Luminaire ................................................................ 2.3

Figure 2.3. LSI Type V Distribution for 400W Luminaire................................................................... 2.3

Figure 2.4. LSI Type III Distribution for 400W Luminaire.................................................................. 2.4

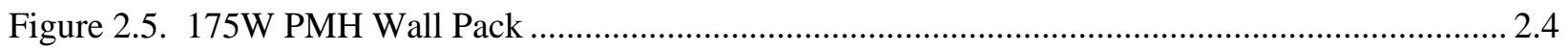

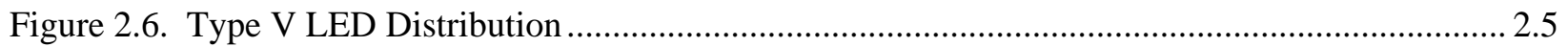

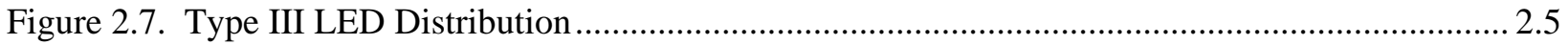

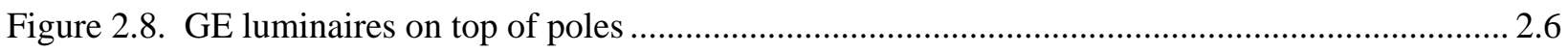

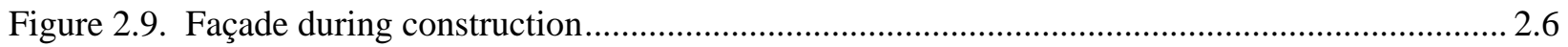

\section{Tables}

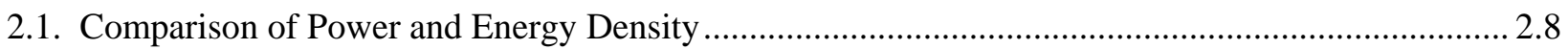

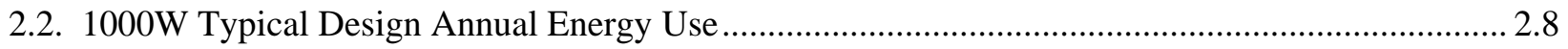

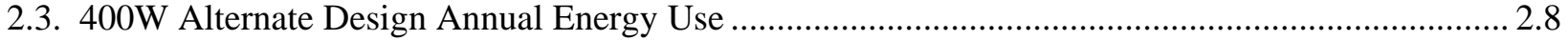

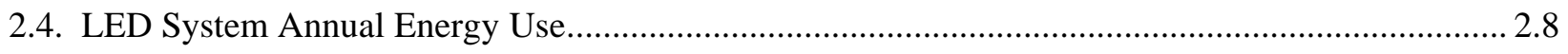

2.5. 1000W Typical PMH Design Illuminance at Time of Relamping................................................. 2.9

2.6. 400W Optional PMH Design Illuminance at Time of Relamping .................................................. 2.9

2.7. LED System Design Illuminance at Time of Relamping.......................................................... 2.10

2.8. LED System Design Calculation of Grid................................................................................... 2.10

2.9. LED System Measurements from May 13, 2009 ........................................................................ 2.10

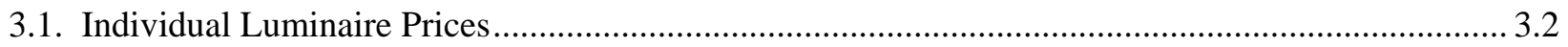

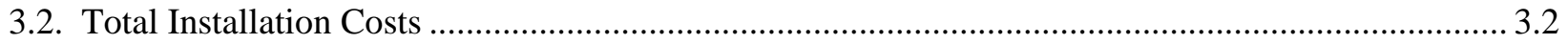

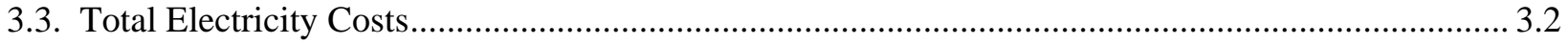

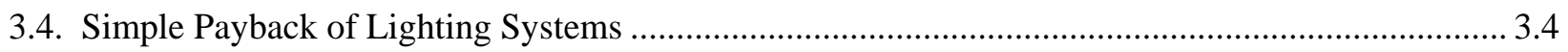

3.5. Net Present Value Review of Lighting Systems ............................................................................. 3.4

5.1. LCC and Payback Comparison of Different Electricity Rates........................................................ 5.2 


\subsection{Introduction}

This report documents the first full parking lot installation of light-emitting diode (LED) products for Walmart, which was done at a Walmart Supercenter in Leavenworth, Kansas. For years, Walmart has explored alternatives to conventional (metal halide [MH] or high-pressure sodium) lighting technologies in its parking lots as a way to save energy, improve the environmental aspects of operation, and potentially reduce maintenance costs. However, the company has approached LED luminaires cautiously pending additional research and analysis.

In 2008, the U.S. Department of Energy (DOE) formed the Retailer Energy Alliance (REA), which brings together similar types of end users to exchange information and leverage buying capacity in order to help expedite market adoption of energy efficient technologies and design practices. ${ }^{1}$ The REA encompasses several different building system subcommittees (e.g., electrical, mechanical, renewable power). A working group was formed as part of the Lighting \& Electrical Subcommittee, of which Walmart is an active participant, to develop an LED parking lot specification. Version 1.2 of the LED parking lot specification was completed in June 2009 and was subsequently expanded to encompass other energy alliances across the broader Commercial Building Energy Alliance (CBEA) (EERE 2011).

With this milestone completed, Walmart agreed to install LEDs across an entire site and in the process "test drive" the CBEA specification

Walmart had already installed a few LED luminaires at their headquarters in Bentonville, Arkansas, but had never done such a large-scale installation. Walmart historically had concerns about the cost and reliability of LEDs; however, lower LED prices and the CBEA specification's emphasis on LED reliability helped address Walmart's concerns and justify a change in practice.

The CBEA specification differs somewhat from the traditional Walmart lighting specification, most notably in requirements for lighting power density and illuminance. Walmart's specification does not have a power density requirement and typically focuses on average illuminance at their sites. IES RP-2098 sets minimum rather than average illuminance requirements, however, and Walmart was a proponent of using minimum illuminance requirements during the specification development process. Others in the working group agreed that minimum values should be specified in lieu of average values.

Like most retailers, Walmart typically requires much higher illuminance values than recommended in RP-20. ${ }^{2}$ In general, Walmart's standard Supercenter parking lot lighting design uses very efficient 1000W pulse-start metal halide (PMH) luminaires and 175W PMH wall packs, together creating light levels that are twice the CBEA specification's minimum required illuminance values. Additionally, the PMH luminaires require biennial relamping (per Walmart's maintenance records), which results in significant maintenance costs.

\footnotetext{
${ }^{1}$ The Retailer Energy Alliance is under the larger DOE initiative, Commercial Building Energy Alliance. Information about the REA can be found at: http://www1.eere.energy.gov/buildings/alliances/retailer_energy_alliance.html.

${ }^{2}$ Section 2.0 of RP-20-98 states, "For example, retailers may prefer higher levels of illuminance than specified herein, to attract customers or to more strongly address perceptions of personal security needs." Section 4.1 further expands on that statement: "Many retailers prefer even higher levels, with a specification of 10 lux (1 fc) as the minimum value.”
} 
The Leavenworth site offered a suitable test case to see if an LED system could meet the CBEA specification requirements while being competitive with conventional systems when maintenance and energy costs were figured into the equation. For this project, Walmart selected GE Lighting's Evolve LED pole-mounted luminaires. Because Leavenworth was a new site, the pole layout could be designed specifically for these luminaires. The typical parking area lighting design also includes wall-mounted luminaires; however, because GE did not manufacture an LED wall-mounted luminaire at the time of the installation, a PMH wall-mounted luminaire by Lithonia was used instead.

During site review it was acknowledged that matching the illuminance of the standard 1000W PMH with the LED product would be cost prohibitive. At the same time, however, the power density of the 1000W system exceeded the CBEA specification (discussed in more detail later in the report), so the previous standard Walmart system (400W PMH) was also selected for comparison. This evaluation thus includes comparisons of the LED against both the 400W system and the 1000W PMH system. 


\subsection{Methodology}

To provide the basis of this evaluation, this section describes the site, the luminaires installed and considered for the installation, power and energy usage of the different systems considered, and the illuminance produced by each.

\subsection{Site Description}

The site is a newly constructed Walmart Supercenter consisting of a $\sim 170,000 \mathrm{ft}^{2}$ store surrounded by about 527,957 $\mathrm{ft}^{2}$ ( $\approx 12$ acres) of parking and other hardscape. Approximately 833 parking spaces are available on site. Unlike many parking lots, which are paved with asphalt, the parking lot is paved with concrete.

\subsection{Designs Considered}

Walmart typically lights a site via pole-mounted area lighting, but in this design Walmart used more wall packs than they typically do. The designs considered included the following equipment:

“Default High-Intensity Discharge (HID) Design” included:

- 9 Type II pole-mounted luminaires with 1000W PMH lamps mounted $39 \mathrm{ft}$ above finished grade $(\mathrm{AFG})^{3}$

- 9 poles with single configuration

- 38 Type V pole-mounted luminaires with 1000W PMH lamps mounted $39 \mathrm{ft}$ AFG

- 10 poles with triple ( 3 at $90^{\circ}$ ) configuration

- 4 poles with back-to-back $\left(2\right.$ at $\left.180^{\circ}\right)$ configuration

- 22 wall-mounted luminaires with 175W PMH lamps

“Alternative HID Design” included:

- 15 Type III pole-mounted luminaires with 400W PMH lamps mounted $37.5 \mathrm{ft}$ AFG

- 4 poles with back-to-back ( 2 at $180^{\circ}$ ) configuration

- 7 poles with single configuration

- 59 Type V pole-mounted luminaires with 400W PMH lamps mounted $37.5 \mathrm{ft}$ AFG

- 13 poles with triple ( 3 at $90^{\circ}$ ) configuration

- 4 poles with back-to-back ( 2 at $180^{\circ}$ ) configuration

- 22 wall-mounted luminaires with 175W PMH

“LED Design” included:

- 12 Type III pole-mounted LED-dedicated luminaires mounted $37.5 \mathrm{ft}$ AFG

- 5 poles with back-to-back ( 2 at $180^{\circ}$ ) configuration

\footnotetext{
${ }^{3}$ Type II distribution might be atypical for some parking lots. This distribution provided the ideal distribution for the pole layout of this design.
} 
- 2 poles with single configuration

- 80 Type V pole-mounted LED-dedicated luminaires mounted $37.5 \mathrm{ft}$ AFG

- 10 poles with quad $\left(4\right.$ at $90^{\circ}$ ) configuration

- 8 poles with triple $\left(3\right.$ at $90^{\circ}$ ) configuration

- 8 poles with back-to-back $\left(2\right.$ at $180^{\circ}$ ) configuration

- 22 wall-mounted luminaires with 175W PMH lamps

Designs for both the $1000 \mathrm{~W}$ and the $400 \mathrm{~W}$ systems were reviewed via computer simulation (AGi$32)^{4}$ for comparison with the LED design and installation.

\subsection{Conventional Luminaires}

As a result of the light trespass requirements in the CBEA specification and to achieve some of the necessary illuminance/uniformity ratios, this installation required more wall-mounted luminaires than is usual for a Walmart site.

For a theoretical baseline design, conventional products from LSI Industries, Inc. (LSI) were chosen because LSI is a Walmart vendor for conventional (non-LED) equipment and has supplied luminaires for other Walmart sites. (LSI now offers LED luminaires; but at the time of the design phase of this project and analysis they did not.) The analysis of hypothetical designs did not include LED LSI luminaires to limit the overall number of possible hypothetical installations.

\subsection{1 "Typical Design" - 1000W Luminaires}

The LSI Type V luminaires (catalog code GFR-540-1000-PSMV-F) have a backlight, uplight, and glare (BUG) rating of B5-U3-G5. ${ }^{5}$ The ballast input power for the $1000 \mathrm{~W}$ rated lamp is $1080 \mathrm{~W}$. Per the manufacturer's catalog, the initial output of the $1000 \mathrm{~W}$ lamp is 120,000 lumens. The luminaire efficiency is 72.2 percent, which translates to a luminaire efficacy of $(120,000$ initial lumens $\times 72.2$ percent efficiency $/ 1080 \mathrm{~W})=80$ lumens per watt $(\mathrm{lm} / \mathrm{W})$. Figure 2.1 illustrates the intensity distribution of the luminaire.

\footnotetext{
${ }^{4}$ AGi-32 is lighting software manufactured by Lighting Analysts (http://www.lightinganalysts.com) and is one of the lighting calculation and rendering software applications used in the lighting industry.

${ }^{5}$ The IESNA no longer uses cutoff classifications, having replaced it with the Luminaire Classification System (LCS). LCS designates "BUG" ratings for luminaires. The CBEA specification sets limits on these BUG values.
} 


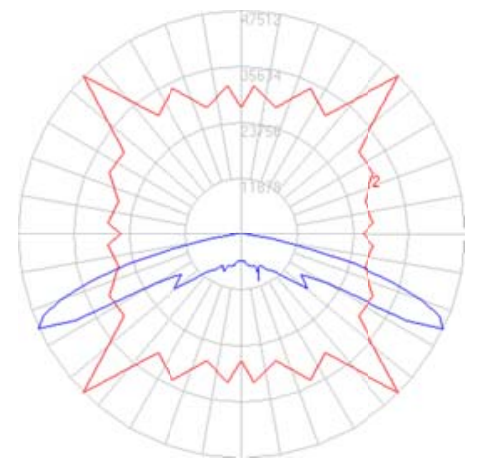

Figure 2.1. LSI Type V Distribution for $1000 \mathrm{~W}$ Luminaire

The LSI Type II luminaires (catalog code GFR-2-1000-PSMV-F) have a BUG rating of B5-U3-G5. The luminaire efficiency is 61percent, which translates to a luminaire efficacy of $67 \mathrm{~lm} / \mathrm{W}$. Figure 2.2 illustrates the intensity distribution of the luminaire.

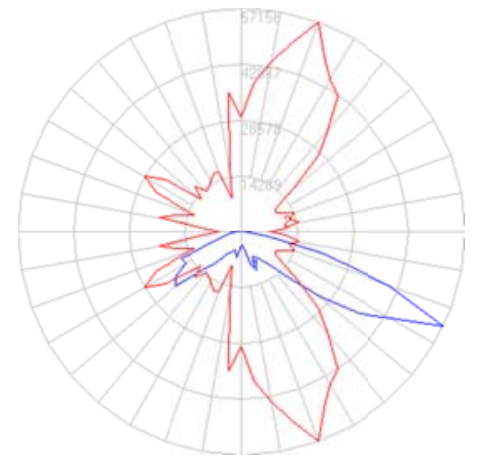

Figure 2.2. LSI Type II Distribution for 1000W Luminaire

\subsubsection{Optional PMH Design - 400W Luminaires}

The LSI Type V luminaires (catalog code GFR-5-400-PSMV-F) have a BUG rating of B5-U2-G5. The ballast input power for the $400 \mathrm{~W}$ lamp was assumed to be $454 \mathrm{~W}$. Per the lamp manufacturer catalog, the initial output of the lamp is 42,000 lumens. The luminaire efficiency is 59 percent, which translates to a luminaire efficacy of $55 \mathrm{~lm} / \mathrm{W}$. Figure 2.3 illustrates the intensity distribution of this luminaire.

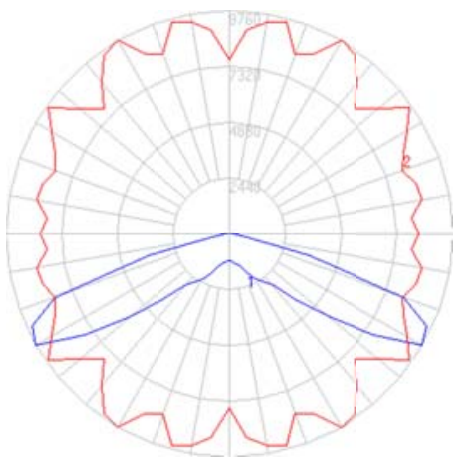

Figure 2.3. LSI Type V Distribution for 400W Luminaire 
The LSI Type III luminaires (catalog code GFR-3-400-PSMV-F) have a BUG rating of B3-U3-G3. The luminaire efficiency is 53 percent, which translates to a luminaire efficacy of $49 \mathrm{~lm} / \mathrm{W}$. Figure 2.4 illustrates the intensity distribution of this luminaire.

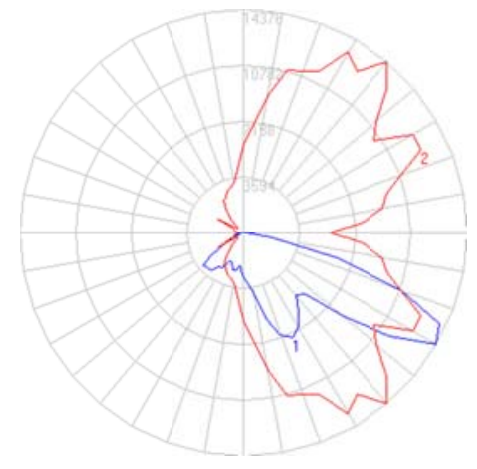

Figure 2.4. LSI Type III Distribution for 400W Luminaire

\subsection{Wall Pack Luminaires}

The wall-mounted luminaires selected and installed were manufactured by Lithonia. The Lithonia metal halide wall-mounted luminaires (catalog code WST-175MHC-WT-277-DBNJI-LPI) have a BUG rating of B2-U1-G2. The ballast input power is $210 \mathrm{~W}$ for the $175 \mathrm{~W}$ lamp. According to the lamp manufacturer, the initial output of the lamp is 11,900 lumens. The luminaire efficiency is 62 percent, which translates to a luminaire efficacy of $32 \mathrm{~lm} / \mathrm{W}$. Figure 2.5 illustrates the intensity distribution of the luminaire. ${ }^{6}$

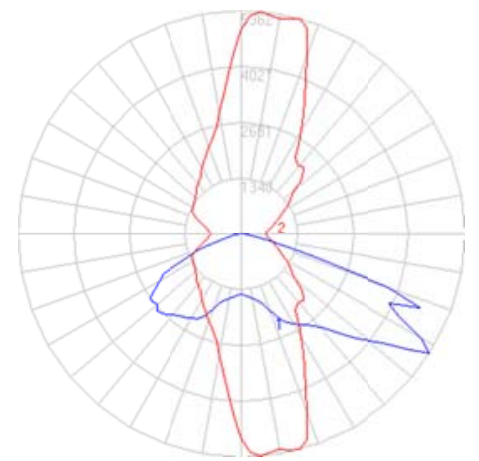

Figure 2.5. 175W PMH Wall Pack

\subsection{LED Luminaires}

The GE Evolve LED Type V Series luminaires (catalog code EAM-H-S5-N-5-A-1-C-BLCK) have a BUG rating of B4-U3-G2. The luminaire efficacy calculated from the manufacturer's IES data file is 57 $\mathrm{lm} / \mathrm{W}\left(11,980\right.$ initial lumens / 210W). ${ }^{7}$ Figure 2.6 illustrates the intensity distribution of the luminaire.

\footnotetext{
${ }^{6}$ Photometry was not available for the 175W PMH wall pack. Photometry values used were estimated from photometric file for LSI fixture WST-150M-WT.

${ }^{7}$ Per IES LM-79-08, LED luminaires are measured via absolute photometry and the entire luminaire is measured via the apparatus. In contrast, conventional (HID) luminaires are typically measured via relative photometry, where the
} 


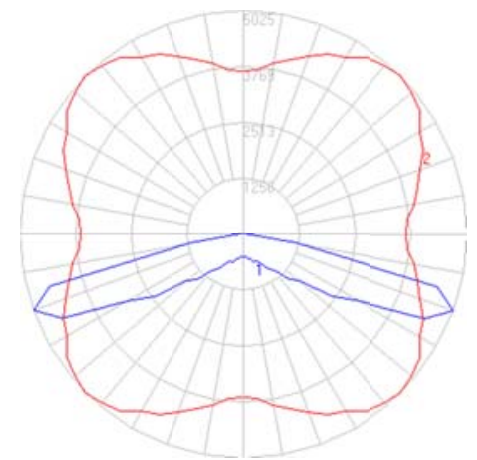

Figure 2.6. Type V LED Distribution

The GE Evolve LED Series Type III luminaires (catalog code EAM-H-W3-N-5-A-1-C-BLCK) have a BUG rating of B2-U2-G2. The luminaire efficacy calculated from the manufacturer's IES data file is 43 $\mathrm{lm} / \mathrm{W}$ (6,679 initial lumens/ 155W). Figure 2.7 illustrates the intensity distribution of the luminaire.

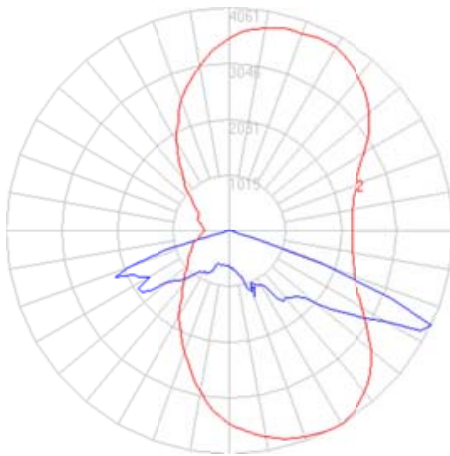

Figure 2.7. Type III LED Distribution

\subsection{Differences in Luminaire Efficacy}

Different elements influence the effectiveness of the design. At a fundamental level, inefficient luminaires lead to inefficient system design. However, different components and different distributions translate to different luminaire efficacies. Ultimately, correct distribution for the given application can be much more important to efficient installation than overall luminaire efficacy.

\subsubsection{Conventional Component Efficiencies}

With conventional magnetic ballast technology, as rated power of the system increases, so typically does the ballast efficiency ( Power $_{\text {Out }} /$ Power $_{\text {In }}$ ). For example, the $1000 \mathrm{~W}$ ballast draws a total of $1080 \mathrm{~W}$, which means that 8 percent of the total power is used by the ballast. In contrast, the $400 \mathrm{~W}$ ballast draws a total of $454 \mathrm{~W}$, or about 14 percent of total power used by the ballast. PMH lamp efficacy is similar in that efficacy increases with rated power. The $400 \mathrm{~W}$ lamp has a lamp rated efficacy (lamp lumens / lamp rated power) of $105 \mathrm{~lm} / \mathrm{W}$, while the $1000 \mathrm{~W}$ lamp has a lamp rated efficacy of $112 \mathrm{~lm} / \mathrm{W}$. When these

luminaire and light source are tested separately. Whereas relative photometry produces a fixture efficiency value, data from absolute photometry does not. 
two systems are combined, the $1000 \mathrm{~W}$ lamp/ballast system operates at $103 \mathrm{~lm} / \mathrm{W}$ and the $400 \mathrm{~W}$ lamp/ballast system operates at a slightly lower system efficacy of $93 \mathrm{~lm} / \mathrm{W}$.

\subsection{Installation}

The standard 1000W PMH lighting design would have required 47 luminaires mounted at $39 \mathrm{ft}$ AFG on 23 poles distributed across the site. In comparison, the "optional PMH design” would have used 74 400W luminaires mounted at $37.5 \mathrm{ft}$ AFG on 33 poles distributed across the site. The LED system actually installed uses 92 LED luminaires (shown in Figure 2.8 on top of the pole) mounted $37.5 \mathrm{ft}$ AFG on 33 poles. All three designs use $22175 \mathrm{~W}$ wall-mounted luminaires that supplement the pole-mounted lighting. Figure 2.9 shows the site with LED luminaires during construction. The lower lumen packages of the 400W PMH system and the LED system require both more luminaires and a slightly lower mounting height to achieve the desired results.

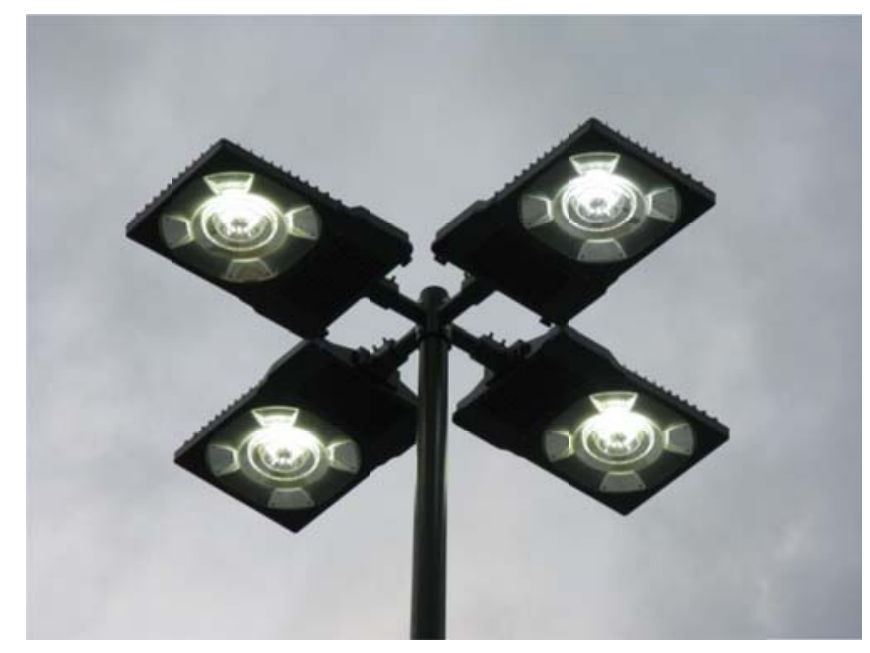

Figure 2.8. GE luminaires on top of poles

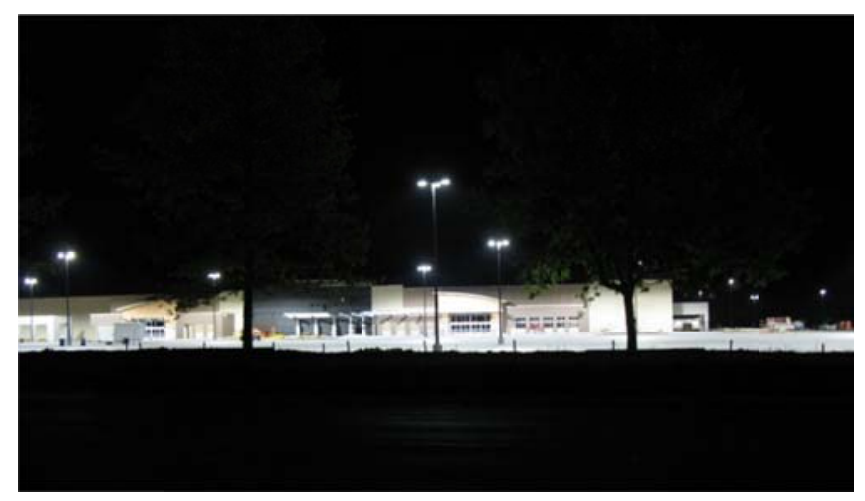

Figure 2.9. Façade during construction

Poles represent the largest expenditure in site/area lighting. Added to the cost of the poles are costs of the required infrastructure work such as trenching and repaving, and materials and installation of conduit, power cable, and the pole support bases. The luminaire is a relatively small component of the overall cost by comparison. For this reason, the usual focus in an installation is on limiting the number of poles. 
However, at this site Walmart was committed to optimizing the design for LEDs regardless of the additional poles needed.

During the site survey and illuminance measurements in May 2009, it was discovered that one pole was $13 \mathrm{ft}$ from intended location. The pole was subsequently moved to the correct location.

\subsection{Power and Energy}

Walmart typically operates their luminaires all night and does not use any controls to reduce the lighting during this period. Therefore, a simple spot power measurement multiplied by the operating hours yields the energy usage estimates.

\subsubsection{Luminaire Power}

Based on manufacturer catalogs, the assumed total input power for the conventional luminaires was $1080 \mathrm{~W}$ for the $1000 \mathrm{~W}$ lamps, $454 \mathrm{~W}$ for the $400 \mathrm{~W}$ lamps, and $210 \mathrm{~W}$ for the $175 \mathrm{~W}$ lamps.

Manufacturer values for the Type V LED luminaire (211W) and the Type III (164W) are used in this report.

\subsubsection{Operating Hours}

The Walmart standard Supercenter exterior lighting system operates sunset to sunrise (11.5 hours per day), or 4200 hours per year. ${ }^{8}$

\subsubsection{Lighting Power Density}

Many energy codes—including ANSI/ASHRAE/IES Standard 90.1, International Energy Conservation Code, and California's Title 24-are either setting or revising power density limits (watts per square foot) for parking lots. The CBEA specification similarly sets a power density limit to guarantee that efficient equipment is used wisely to meet the needs of the site. The CBEA specification establishes power densities by ambient lighting zone: ${ }^{9}$ (CBEA 2010)

- LZ2 - 0.05 watts per square foot

- LZ3 - 0.06 watts per square foot

- LZ4 - 0.08 watts per square foot

Because this Walmart is located near other stores, the site qualifies as ambient Lighting Zone 3, with a maximum allowable lighting power density (LPD) of 0.06 watts per square foot per the CBEA specification.

\footnotetext{
${ }^{8} 11.5$ hours per day is from Section 4.2 of IESNA DG-13-98, Guide for the Selection of Photocontrols for Outdoor Lighting Applications.

${ }^{9}$ See the CBEA definition of the lighting zones.
} 
Table 2.1. Comparison of Power and Energy Density

\begin{tabular}{cc}
\hline & Lighting Power Density \\
\hline CBEA Specification & $0.06 \mathrm{~W} / \mathrm{ft}^{2}$ \\
1000W Typical & $0.10 \mathrm{~W} / \mathrm{ft}^{2}$ \\
400W Alternate & $0.07 \mathrm{~W} / \mathrm{ft}^{2}$ \\
Leavenworth LED Design & $0.04 \mathrm{~W} / \mathrm{ft}^{2}$ \\
\hline
\end{tabular}

Neither the 1000W system nor the 400W system meets the stringent LPD of the CBEA specification, even though this was one of the reasons the alternate $400 \mathrm{~W}$ system was designed.

\subsubsection{Lighting System Energy Usage}

The following tables provide the power draw per luminaire type and total energy consumption of the three different lighting systems. The values reported in the tables represent catalog data rather than measured values.

Table 2.2. 1000W Typical Design Annual Energy Use

\begin{tabular}{|c|c|c|c|c|c|}
\hline Qty & Arrangement & Luminaire Power (W) & Total Power (W) & Hours & Energy (kWh) \\
\hline 38 & Type V & 1,080 & 41,040 & 4,200 & 172,368 \\
\hline 9 & Type II & 1,080 & 9,720 & 4,200 & 40,824 \\
\hline 22 & Wall mounted & 210 & 4,620 & 4,200 & 19,404 \\
\hline \multicolumn{5}{|c|}{ TOTAL ANNUAL ENERGY USE } & 232,596 \\
\hline
\end{tabular}

Table 2.3. 400W Alternate Design Annual Energy Use

\begin{tabular}{|c|c|c|c|c|c|}
\hline Qty & Arrangement & Luminaire Power (W) & Total Power (W) & Hours & Energy (kWh) \\
\hline 59 & Single, Type V & 454 & 26,786 & 4,200 & 111,501 \\
\hline 15 & Single, Type III & 454 & 6,810 & 4,200 & 28,602 \\
\hline 22 & Wall mounted & 210 & 4,620 & 4,200 & 19,404 \\
\hline \multicolumn{5}{|c|}{ TOTAL ANNUAL ENERGY USE } & 160,507 \\
\hline
\end{tabular}

Table 2.4. LED System Annual Energy Use

\begin{tabular}{cccccc}
\hline Qty & Arrangement & Luminaire Power (W) & Total Power (W) & Hours & Energy (kWh) \\
\hline 80 & Single, Type V & 211 & 16,880 & 4,200 & 70,896 \\
12 & Single, Type III & 164 & 1,968 & 4,200 & 8,266 \\
22 & Wall mounted & 210 & 4,620 & 4,200 & 19,404 \\
& & & TOTAL ANNUAL ENERGY USE & 98,565 \\
\hline
\end{tabular}

The 1000W PMH system is expected to use 233 megawatt-hours (MWh) of energy annually, compared to the alternative 400W PMH system's expected use of $161 \mathrm{MWh}$ and the LED system's 99 MWh. The LED system thereby uses 38 percent less electricity than the $400 \mathrm{~W}$ system and 57 percent less than the standard $1000 \mathrm{~W}$ system. 


\subsection{Illuminance}

Illuminance measurements for the installed LED product were taken on May 13, 2009 by GE personnel, with Pacific Northwest National Laboratory and Walmart representatives reviewing the procedure as the values were recorded.

\subsubsection{Designed/Calculated Values}

Illuminance was calculated across the entire site, encompassing all of the luminaires as well as light loss factors (LLF). These calculations are summarized below.

A site of this size $\left(>500,000 \mathrm{ft}^{2}\right)$ is difficult to measure in its entirety; thus, the overall site was calculated and only selected portions of it physically measured. To calibrate the actual measured values to the calculated values, smaller grids correlating to the actual measured points were calculated as well. The data related to these smaller grids can be found in Section 2.9.1.2. These values represent initial illuminance, corresponding to what was measured (i.e., initial lumens).

\subsubsection{Entire Site Illuminance Calculations}

The CBEA specification divides the parking lot into different sections, or zones (main, perimeter, front aisle, rear drive, etc.), because each zone has its own illuminance requirements. The following tables use freely available IES-format files for the products mentioned in Sections 2.3 and 2.5.

The CBEA specification required a minimum of 0.75 footcandles (fc) for this site at the time that the luminaires were replaced. Per the specification and IES guidelines, LLF was included in the calculations. For PMH luminaires, the calculations that created Table 2.5 through Table 2.7 used lamp lumen depreciation values of 0.75 for the metal halide luminaires and 0.70 for LED luminaires. ${ }^{10}$

Table 2.5. 1000W Typical PMH Design Illuminance at Time of Relamping

\begin{tabular}{lccccc}
\hline $\begin{array}{l}\text { Section of } \\
\text { Parking Lot }\end{array}$ & $\begin{array}{c}\text { Minimum } \\
\text { Illuminance } \\
(\mathrm{fc})\end{array}$ & $\begin{array}{c}\text { Maximum } \\
\text { Illuminance } \\
(\mathrm{fc})\end{array}$ & $\begin{array}{c}\text { Average } \\
\text { Illuminance } \\
(\mathrm{fc})\end{array}$ & Avg/Min & Max/Min \\
\hline Front Aisle & 3.7 & 8.2 & 6.1 & $1.6: 1$ & $2.2: 1$ \\
Main Lot & 1.7 & 8.2 & 4.6 & $2.7: 1$ & $4.8: 1$ \\
\hline
\end{tabular}

Table 2.6. 400W Optional PMH Design Illuminance at Time of Relamping

\begin{tabular}{lccccc}
\hline $\begin{array}{l}\text { Section of } \\
\text { Parking Lot }\end{array}$ & $\begin{array}{c}\text { Minimum } \\
\text { Illuminance } \\
\text { (fc) }\end{array}$ & $\begin{array}{c}\text { Maximum } \\
\text { Illuminance } \\
\text { (fc) }\end{array}$ & $\begin{array}{c}\text { Average } \\
\text { Illuminance } \\
(\mathrm{fc})\end{array}$ & Avg/Min & Max/Min \\
\hline Front Aisle & 2.5 & 4.6 & 3.2 & $1.3: 1$ & $1.8: 1$
\end{tabular}

\footnotetext{
${ }^{10}$ Section 6.1.4, Lumen Maintenance, of RP-20-98 states, "Each design should provide the required minimum lighting levels at time of relamping. Therefore, design should be based on the relamping program to be used.” The end of useful life for LED systems is when the light output reaches $70 \%$ of initial output, or $\mathrm{L}_{70}$. The CBEA specification requires $\mathrm{L}_{70}$ (or a lamp lumen depreciation of 0.70 ) to be used in the design calculations/documentation.
} 
Table 2.7. LED System Design Illuminance at Time of Relamping

\begin{tabular}{lccccc}
\hline $\begin{array}{l}\text { Section of } \\
\text { Parking Lot }\end{array}$ & $\begin{array}{c}\text { Minimum } \\
\text { Illuminance } \\
(\mathrm{fc})\end{array}$ & $\begin{array}{c}\text { Maximum } \\
\text { Illuminance } \\
(\mathrm{fc})\end{array}$ & $\begin{array}{c}\text { Average } \\
\text { Illuminance } \\
(\mathrm{fc})\end{array}$ & Avg/Min & Max/Min \\
\hline Front Aisle & 1.2 & 1.8 & 1.5 & $1.3: 1$ & $1.5: 1$ \\
Main Lot & 0.8 & 1.9 & 1.3 & $1.6: 1$ & $2.4: 1$ \\
\hline
\end{tabular}

Each system considered thus meets the CBEA specification minimum requirement of $0.75 \mathrm{fc}$ at the time of the light source replacement.

\subsubsection{Measurement Grid Calculations}

To verify the design calculations, field measurements were planned. However, gathering all of those measurement points is virtually impossible. Therefore, representative grids correlating to the measurements taken in the field were calculated along with the entire site. Because multiple field measurements were taken, different calculation grids were created. Table 2.8 corresponds to the initial illuminance values calculated for the site.

Table 2.8. LED System Design Calculation of Grid

\begin{tabular}{lccccc}
\hline $\begin{array}{l}\text { Section of } \\
\text { Parking Lot }\end{array}$ & $\begin{array}{c}\text { Minimum } \\
\text { Illuminance } \\
\text { (fc) }\end{array}$ & $\begin{array}{c}\text { Maximum } \\
\text { Illuminance } \\
\text { (fc) }\end{array}$ & $\begin{array}{c}\text { Average } \\
\text { Illuminance } \\
\text { (fc) }\end{array}$ & Avg/Min & Max/Min \\
\hline Front Aisle & 1.9 & 2.7 & 2.3 & $1.2: 1$ & $1.4: 1$ \\
Main Lot & 1.4 & 1.8 & 1.5 & $1.1: 1$ & $1.3: 1$ \\
Perimeter & 0.8 & 1.1 & 0.9 & $1.1: 1$ & $1.4: 1$ \\
\hline
\end{tabular}

\subsubsection{Measured Values}

Table 2.9 provides the summary of the field measurements.

Table 2.9. LED System Measurements from May 13, 2009

\begin{tabular}{lccccc}
\hline $\begin{array}{l}\text { Section of } \\
\text { Parking Lot }\end{array}$ & $\begin{array}{c}\text { Minimum } \\
\text { Illuminance } \\
(\mathrm{fc})\end{array}$ & $\begin{array}{c}\text { Maximum } \\
\text { Illuminance } \\
(\mathrm{fc})\end{array}$ & $\begin{array}{c}\text { Average } \\
\text { Illuminance } \\
(\mathrm{fc})\end{array}$ & Avg/Min & Max/Min \\
\hline Front Aisle & 1.6 & 2.5 & 2.1 & $1.3: 1$ & $1.6: 1$ \\
Main Lot & 0.9 & 1.7 & 1.3 & $1.4: 1$ & $1.8: 1$ \\
Perimeter & 0.4 & 1.2 & 0.7 & $1.2: 1$ & $1.6: 1$ \\
\hline
\end{tabular}

Section 5.2 reviews why predicted values (Table 2.8) may not match exactly with the measured values (Table 2.9) in the field. 


\subsection{Cost Effectiveness}

In this section, the economics of the LED system are compared against both HID systems- the current standard 1000W and the previous standard 400W. Simple payback, life-cycle costs (LCC), and internal rate of return are estimated. Because the 22 wall packs are consistent across all the designs and these luminaires are not pole-mounted, they are equivalent across systems and are therefore ignored in the calculations.

\subsection{Inputs for Economic Analysis}

The initial higher costs of LED luminaires are theoretically more than offset by reduced electricity and deferred maintenance costs over the life of the LED luminaire. Walmart expects these LED luminaires to last 10 years, so this economic analysis models the LCCs of all three Leavenworth lighting systems over that timeframe. The Building Life-Cycle Cost (BLCC) software developed by the National Institute of Standards and Technology was used to calculate the LCC for infrastructure-related energy conservation projects that have high initial costs, but save energy over the long term. ${ }^{11}$ This program was used to model the present value LCC of the three lighting designs. Each system is evaluated in terms of estimated luminaire costs, installation costs, projected 10-year maintenance costs, and projected 10-year energy $\operatorname{costs}^{12}$, and the analysis accounts for expected changes in energy prices.

\subsubsection{Cost of Equipment}

Walmart competitively bids out their equipment needs to vendors that can deliver products that meet Walmart's stringent specifications at very low prices. The costs used in Table 3.1 essentially constitute what a general contractor would pay for such luminaires per manufacturer's representatives for that area of the country. Because each of the designs used a different number of poles and different number of luminaires, Table 3.2 compares the total cost of each system as designed using the individual luminaire prices from Table 3.1 .

\footnotetext{
${ }^{11}$ This software is available for download at http://www1.eere.energy.gov/femp/information/download blcc.html.

${ }^{12}$ This evaluation uses representative rather than real costs for the site due to the business sensitivity of such information.
} 
Table 3.1. Individual Luminaire Prices

\begin{tabular}{ccccccc}
\hline & $\begin{array}{c}\text { Light } \\
\text { Source }\end{array}$ & $\begin{array}{c}\text { Luminaire } \\
\text { Nominal Power } \\
(\mathrm{W})\end{array}$ & $\begin{array}{c}\text { Luminaire } \\
\text { Distribution }\end{array}$ & $\begin{array}{c}\text { Luminaire } \\
\text { Price } \\
(\mathbf{\$})\end{array}$ & $\begin{array}{c}\text { Quantity } \\
\text { Total Price } \\
(\mathbf{\$})\end{array}$ \\
\hline Baseline & PMH & 1000 & Type II & 881 & 9 & 7,929 \\
Design & PMH & 1000 & Type V & 881 & 38 & 33,478 \\
& MH & 175 & & --- & 22 & --- \\
Alternate & PMH & 400 & Type III & 685 & 15 & 10,275 \\
Design & PMH & 400 & Type V & 685 & 59 & 40,415 \\
& MH & 175 & & --- & 22 & -- \\
& & & & & Total & $\mathbf{5 0 , 6 9 0}$ \\
Installed & LED & 164 & Type III & 1200 & 12 & 14,400 \\
Design & LED & 211 & Type V & 1000 & 80 & 80,000 \\
& MH & 175 & & --- & 22 & -- \\
& & & & & Total & $\mathbf{9 4 , 4 0 0}$ \\
\hline
\end{tabular}

Table 3.2. Total Installation Costs

\begin{tabular}{lccccc}
\hline & $\begin{array}{c}\text { \# of } \\
\text { Poles }\end{array}$ & $\begin{array}{c}\text { Materials \& Installation } \\
\text { Cost per Pole } \\
(\$)\end{array}$ & $\begin{array}{c}\text { Total Pole } \\
\text { Cost } \\
(\$)\end{array}$ & $\begin{array}{c}\text { Luminaires Prices } \\
\text { Table 3.1 } \\
(\$)\end{array}$ & $\begin{array}{c}\text { Total Costs } \\
(\$)\end{array}$ \\
\hline Typical Design & 23 & 1,600 & 36,800 & 41,407 & 78,207 \\
Alternate Design & 33 & 1,600 & 52,800 & 50,690 & 103,490 \\
Installed Design & 33 & 1,600 & 52,800 & 94,400 & 146,800 \\
\hline
\end{tabular}

\subsubsection{Cost of Electricity}

In the U.S., commercial electricity prices vary greatly by state and region. As a reference point, the U.S. Energy Information Administration (EIA) publishes the Average Retail Price of Electricity to Ultimate Customers by End-Use Sector by State (EIA 2011). The national average retail price of electricity to commercial customers in October 2009 was reported as $\$ 0.1022 / \mathrm{kWh}$. The Leavenworth site's estimated electricity cost of $\$ 0.056 / \mathrm{kWh}^{13}$ is low not just in relation to most regions of the country, but also within Kansas. In general, LEDs are likelier to be economically viable in places where electricity costs are high enough that the energy savings they generate contribute significantly to paying back the high initial costs of these luminaires.

Using the annual energy usage of the different lighting systems from Section 2.8 and the electricity rate of $\$ 0.056$, the total annual energy costs of the light fixtures are shown in Table 3.3.

Table 3.3. Total Electricity Costs

\begin{tabular}{lcc}
\hline Yearly Operation & Cost of Electricity & Annual Costs \\
\hline
\end{tabular}

\footnotetext{
${ }^{13}$ Westar Energy is the energy supplier in Leavenworth, and energy costs for this report were calculated using an estimated $\$ 0.056 / \mathrm{kWh}$ average quote for a commercial customer with an equivalent-sized store and parking area.
} 


\begin{tabular}{lccc}
\hline & $(\mathrm{kWh})$ & $(\$ / \mathrm{kWh})$ & $(\$)$ \\
\hline Typical PHM Design & 232,596 & 0.056 & $\$ 13,025.38$ \\
Alternate PMH Design & 160,507 & 0.056 & $\$ 8,988.39$ \\
Installed LED Design & 98,565 & 0.056 & $\$ 5,519.64$ \\
\hline
\end{tabular}

\subsubsection{Cost of Operation}

Walmart's estimated maintenance costs for the PMH systems includes scheduled maintenance, equipment costs (group relamp every 2 years), and unscheduled maintenance costs (the cost of labor and materials to fix a luminaire). The PMH systems cost $\$ 74$ per luminaire per year to maintain. The annual per-luminaire maintenance cost for the LED system is based on estimated costs for unscheduled repairs and maintenance. Although these luminaires are not expected to need much maintenance, an estimated amount has been allocated to cover the labor and material costs associated with fixing a luminaire. The assumed maintenance cost for the LED system is \$20 per luminaire per year. Since maintenance costs include more than lamp replacements, a sum of \$20 was included to account for some unexplained maintenance.

\subsubsection{Discount Rate}

Discount is a component representing the time value of money. Walmart's discount rate is 3.84 percent. In other analyses, per the Office of Management and Budget, DOE uses discount rates of 3 percent and 7 percent to cover the range of typical discount rates for institutions in the country. Walmart's discount rate is in the low-end of the range, which isn't surprising given their size, capital situation, and management practice of reviewing every cost of operation.

\subsubsection{Analysis Period}

Walmart negotiated a 10-year warranty with GE Lighting for the LED luminaires, in line with their plan to replace the LED luminaires in that timeframe. Thus, the life-cycle analysis period for the luminaires is also 10 years.

\subsection{Simple Payback}

Simple payback does not factor in the cost of the money over time. For this analysis, the total difference in initial cost of the different systems is calculated and divided by the annual savings from reduced energy and maintenance. 
Table 3.4. Simple Payback of Lighting Systems

\begin{tabular}{lccc}
\hline \multicolumn{1}{c}{ Item } & $\begin{array}{c}\text { 1000W PMH } \\
\text { Typical Design }\end{array}$ & $\begin{array}{c}\text { 400W PMH } \\
\text { Alternative }\end{array}$ & LED Installed \\
\hline Pole Count & 23 & 33 & 33 \\
\hline Luminaire Count & 47 & 74 & 92 \\
\hline First Cost of System & $\$ 78,207$ & $\$ 103,490$ & $\$ 146,800$ \\
\hline Annual Energy Costs & $\$ 13,025.38$ & $\$ 8,988.39$ & $\$ 5,519.64$ \\
\hline Annual Energy Savings & $\$ 7,505.74$ & $\$ 3,468.75$ & --- \\
\hline Annual Maintenance Costs & $\$ 3,478.00$ & $\$ 5,476.00$ & $\$ 1,840.00$ \\
\hline Annual Maintenance Savings & $\$ 1,638.00$ & $\$ 3,636.00$ & -- \\
\hline Annual Savings & $\$ 9,143.74$ & $\$ 7,104.75$ & -- \\
\hline Simple Payback (years) & 7.5 years & 6.1 years & -- \\
\hline
\end{tabular}

\subsection{Net Present Value and Life-Cycle Cost Analysis}

Life-cycle cost analysis provides a consistent basis for comparing products with different lifetimes. The analysis compares the total costs of the products over a given time period and assumes a fixed discount rate to translate those costs back into a present value. As stated in Section 3.1.4, the discount rate is 3.84 percent. Table provides the results of this analysis.

Table 3.5. Net Present Value Review of Lighting Systems

\begin{tabular}{lccc}
\hline \multicolumn{1}{c}{ Item } & $\begin{array}{c}\text { 1000W PMH } \\
\text { Typical Design }\end{array}$ & $\begin{array}{c}\text { 400W PMH } \\
\text { Alternative }\end{array}$ & LED Installed \\
\hline Pole Count & 23 & 33 & 33 \\
\hline Luminaire Count & 47 & 74 & 92 \\
\hline First Cost of System & $\$ 78,207$ & $\$ 103,490$ & $\$ 146,800$ \\
\hline Analysis Period (years) & 10 & 10 & 10 \\
\hline Annual Energy Costs & $\$ 13,025.38$ & $\$ 8,988.39$ & $\$ 5,519.64$ \\
\hline Life-Cycle Energy Cost (PV) & $\$ 130,253.76$ & $\$ 89,883.92$ & $\$ 55,196.40$ \\
\hline Annual Maintenance Costs & $\$ 3,478.00$ & $\$ 5,476.00$ & $\$ 1,840.00$ \\
\hline Lifecycle Maintenance Cost (PV) & $\$ 34,780.00$ & $\$ 54,760.00$ & $\$ 18,400.00$ \\
\hline Total Life-Cycle Cost (PV) & $\$ 243,240.76$ & $\$ 248,133.92$ & $\$ 220,396.40$ \\
\hline Comparison with LED System & $+\$ 22,844.36$ & $+\$ 27,737.52$ & - \\
\hline
\end{tabular}

- $\quad$ Present Value (PV) = The current value of one or more future cash payments, discounted at some appropriate interest rate

\subsection{Summary}

Comparing the costs of the different lighting systems reveals some interesting facts, as described in the following sections. 


\subsubsection{W PMH vs. LED System}

Because the standard 1000W PMH system produces considerably more illuminance than the LED system, the systems are not directly equivalent. The LED system requires different pole spacing and layout and more than double the number of luminaires. However, the $1000 \mathrm{~W}$ system provides much higher illuminance than is recommended by IES for retail parking lot applications. Energy codes and other regulations are moving toward more closely aligning lighting requirements with recommendations, so that the use of such high-wattage systems may become less common.

In any case, higher relative energy costs and maintenance costs makes the $1000 \mathrm{~W}$ system somewhat more expensive than the LED system, by $\$ 22,844$. The simple payback for the LED system occurs after 7.5 years ( $\$ 146,800$ (LED system initial cost) - \$78,207 (1000W PMH system initial cost) / \$9,144 (annual savings from LED system).

\subsubsection{W PMH System vs. LED System}

The 400W PMH system and the installed LED system have similar minimum illuminance levels in the main parking lot, and both systems require 33 poles to adequately light the parking lot at a cost of $\$ 52,800$. However, the LED system requires 92 luminaires to light this parking area versus the $400 \mathrm{~W}$ system's 74-luminaire design, thus requiring $\$ 43,310$ in incremental first costs compared to the $400 \mathrm{~W}$ system. Over the analysis period, the LED system saves a present value of $\$ 34,688$ in energy costs, but energy savings alone does not offset the initial costs of the LED luminaires.

The situation changes when maintenance costs are taken into account, with the LED system saving a present value of $\$ 36,360.00$ in maintenance costs over its life cycle.

In total, the overall present value LCCs of the 400W PMH system are \$248,134 in contrast to the LED system total of $\$ 220,396$, for a relative savings of $\$ 27,738$. Simple payback for the LED system occurs 6.10 years (\$146,800 (LED system initial cost) - \$103,490 (400W PMH system initial cost) / $\$ 7,105$ (annual savings from LED system).

\subsubsection{W PMH vs. 1000W PMH}

Comparing the 400W PMH system to the incumbent 1000W PMH system reveals how fewer luminaires and poles provide notable savings. The 23-pole, 47-luminaire $1000 \mathrm{~W}$ system has a net initial investment savings of $\$ 25,283$ relative to the 33-pole, 74-luminaire 400W system, and the 400W system saves a present value of $\$ 40,370$ in energy costs over the analysis period.

However, when life-cycle maintenance costs are factored in, the difference between these systems becomes less pronounced. The $400 \mathrm{~W}$ system will cost a present value of $\$ 54,760$ over the analyzed period to maintain, whereas the $1000 \mathrm{~W}$ system costs a present value of $\$ 34,780$, for a total savings of $\$ 19,980$. When the initial cost of equipment, the cost of energy for the systems for 10 years, and the cost of maintenance are factored in, the 1000W system actually costs $\$ 4,893$ less than the 400W PMH system. Given the higher illuminance values for less money, it is clear why the $1000 \mathrm{~W}$ system has become the standard default design. 


\subsection{Lighting Qualitative Evaluation}

The GATEWAY program considers user feedback on the qualitative aspects of LED lighting to be an essential component of the overall evaluation. Users are likely to resist products that don't illuminate as well as the incumbent technology, and therefore such products are unlikely to be widely adopted regardless of the unit energy savings they offer. In addition, quantitative analysis of the measurements to the exclusion of qualitative feedback does not capture the full effect of the substitution; it disregards other aspects influencing human perception, such as whether lower illuminance is acceptable for the Walmart brand, uniformity of illumination, perceived brightness, safety and security, glare, and light trespass issues. For this evaluation, comments from different groups of people yield qualitative assessments.

\subsection{Owner Evaluation}

In a March 26, 2009 webcast (EERE 2009), Ralph Williams, Walmart Senior MEP Systems Engineer reported the results from several tests, retrofits, and LED evaluations that happened before the Leavenworth installation. In general, he noted that the strengths of LED lighting are uniform illumination and energy savings. The conclusions from these prior evaluations led to a corporate decision to design an entire site with LEDs.

Walmart has been highly impressed by the LEDs' exceptional optical performance, allowing close adherence to light trespass restrictions, zoning requirements, and good neighbor policies. The Leavenworth site, for example, has residences on the east and north sides of the site that comprises lightsensitive borders.

\subsection{Walmart Shopper's Survey}

Walmart conducted exit interviews on a diverse group (varying in age, gender, ethnicity, shopping alone and/or with others) of more than 40 customers, after nightfall outside their Leavenworth location and another store in Peoria, Illinois on Friday, August 7, and Sunday, August 9, 2009. The store in Peoria was lighted by traditional metal halide luminaires (although lighting was different between the two sites) and was determined to serve a similar population base as the Leavenworth site. The two surveys allowed Walmart management to evaluate both lighting systems in terms of customer preference.

Overall, shoppers at both sites were reportedly satisfied by the amount of light provided by the parking lot lighting system, despite the fact that the LED system provides significantly lower illuminance than a traditional 1000W system. However, the Leavenworth site has a concrete parking surface while Peoria has an asphalt surface. Since the parking surface influences the perception of brightness, it is difficult to determine if customers actually liked the lower illuminance from the LED system or if the surface luminance of the two systems is similar and that is what the customers were responding to. At the very least, customers appear to accept the lower lighting levels of the LED system when used with concrete pavement.

Most customers admitted they had never thought about the parking lot lighting. However, when prompted, customers provided positive feedback about both lighting systems. 


\subsection{Discussion}

During this demonstration, many elements of the lighting system required additional analyses. Some of the analyses are new because of the LEDs (lumen depreciation) while others (reflectance, deviations from designs) are typical regardless of the light source.

\subsection{Owner Evaluation}

Walmart considers the installation a success. The installation met their stringent cost-effectiveness requirements and allowed them to test LEDs in a major installation. Since the installation, Walmart has installed LED luminaires at sites in both Mexico and Puerto Rico, where the electricity rate is sufficiently higher than the U.S. national average and thus further favored the cost-effectiveness. However, domestically, Walmart management has not converted to LEDs across the board. Management is not entirely sold on the lower illuminance levels; partially because lower light levels are a deviation from Walmart practice and partially because neighboring retailers often light to a higher level. Finally, parking surface is a factor in management's decision. In another installation with similar illuminance levels, but asphalt rather than concrete, management was not as satisfied. The lower reflectance of asphalt is probably one reason for management's dissatisfaction. Concrete is typically 30 to 40 percent reflective and asphalt is less than 30 percent reflective.

\subsection{Lighting Metrics}

Energy savings is a central component of both GATEWAY demonstrations and the CBEA specification, but achieving sufficient illumination is also of primary concern. Measured illuminance levels varied enough from what was expected to warrant further analysis to identify the root of the differences.

Illuminance is the amount of light falling on a surface and is easy to measure, but does not precisely correlate to what the eye sees. Exitance is the light subsequently reflected off the surface. But it is the intensity of light directed back toward the eye per unit of apparent luminous area, or luminance that is important for vision. The accurate measurement of luminance becomes complicated by the point of view (via either the person or the meter), the type of material (color and texture), the location of the light source, and the type of light source.

Walmart's contractor chose concrete rather than asphalt at this site. Typical concrete has a higher reflectance value than asphalt, along with a smoother, more reflective texture. The higher reflectance values from concrete play as much of a role in the visibility and apparent brightness of the site as the lighting.

\subsection{Cost Effectiveness}

Considering the total LCCs for each of the three luminaire options, LEDs seem a more viable alternative to either of the PMH systems. The greater number of poles and fixtures needed for the 400W system along with its lower efficacy than the $1000 \mathrm{~W}$ system results in the corresponding energy and maintenance savings being even more pronounced over the 10-year period examined. 


\subsubsection{Atypical Costs}

Energy and labor rates differ across regions, states, and metropolitan areas. Kansas, for example, has below average costs in both energy and maintenance (i.e., labor). ${ }^{14}$ Therefore, this installation represents an "acid test" of sorts for applicability of LEDs and the CBEA specification, at least for this retailer. A more generic comparison for the United States might at least use the national average of $\$ 0.1022$ for the electricity rate. Table 5.1 shows such a comparison.

Table 5.1. LCC and Payback Comparison of Different Electricity Rates

\begin{tabular}{|c|c|c|c|c|c|c|}
\hline & \multicolumn{3}{|c|}{$\begin{array}{c}\text { Leavenworth, KS Rate } \\
(\$ 0.056 / \mathrm{kWh})\end{array}$} & \multicolumn{3}{|c|}{$\begin{array}{c}\text { National Average Rate } \\
(\$ 0.1022 / \mathrm{kWh})\end{array}$} \\
\hline & LCC & $\begin{array}{c}\text { LCC } \\
\text { Savings }\end{array}$ & Payback & LCC & LCC Savings & Payback \\
\hline 1000W PMH & $\$ 243,240.76$ & $\$ 22,844.36$ & 7.50 & $\$ 350,700.11$ & $\$ 84,766.68$ & 4.5 \\
\hline 400W PMH & $\$ 248,133.92$ & $\$ 27,737.52$ & 6.10 & $\$ 322,288.15$ & $\$ 56,354.72$ & 4.4 \\
\hline LED System & $\$ 220,396.40$ & --- & & $\$ 265,933.43$ & --- & --- \\
\hline
\end{tabular}

\footnotetext{
${ }^{14}$ The Department of Labor's Bureau of Labor Statistics publishes occupational employment statistics for electricians. The average hourly rate of an electrician in the state of Kansas is slightly lower than the national average.
} 


\subsection{Conclusions}

This demonstration involved two different activities supported by the DOE: the Commercial Building Energy Alliances and the SSL Technology GATEWAY Demonstration Program. Each program measures success differently, but both programs highlight information that is useful from a corporate standpoint.

\subsection{Lighting Power Density}

The CBEA specification specifies different factors to ensure energy efficient, well-lighted parking areas, but the most pertinent factor to this study is its LPD maximum limit of 0.06 watts per square foot. A typical Walmart Superstore site using 1000W luminaires would draw on the order of 0.10 watts per square foot. The alternate baseline design using 400W PMH luminaires draws 0.07 watts per square foot, almost meeting the CBEA specification. Nevertheless, neither the 1000W PMH system nor the 400W PMH system met the LPD requirements at this site, and thus were not strictly viable options for meeting the specification. The installed LED system draws about 0.04 watts per square foot, and was thus the only design of the three that satisfied the requirement.

\subsection{Lower Illuminance}

Illuminance was reduced by half to three-quarters of the standard $1000 \mathrm{~W}$ design levels, bringing them much closer to RP-20 recommendations. Although this approach saves both energy and cost (particularly with LED luminaires), Walmart management has expressed concern about replicating the lower illuminance of the Leavenworth site at other sites. Lighting perception is affected by ambient conditions, and other sites may be located in more densely populated areas with more surrounding light, making the parking lot appear dim by comparison. In addition, other sites may use asphalt rather than concrete and lose some of the reflective benefit achieved in the Leavenworth location. Such concerns will only be alleviated by successfully demonstrating LED products in one or more relevant locations (see "Other Sites” below). There was no indication in this location that customers perceived the parking lot as dim, unsafe, or otherwise insufficiently illuminated.

The Portland Cement Association did a study on the influence of pavement reflectance on lighting for parking lots and found concrete to have a higher luminance than asphalt. (PCA 2005) The higher luminance resulted from concrete absorbing less light and that concrete is generally more diffuse than asphalt. Diffuse reflectance means that a point reflecting light is luminous from more viewing angles.

\subsection{Other sites}

Since the Leavenworth installation, Walmart has completed another site using the CBEA specification, and has more sites under construction and the design stage that all use LED luminaires. Walmart and other sites can expect to find projects more cost-effective where the electricity rate is either at or greater than the national average. Additional experience with lighting the parking lots using LED luminaires will provide more information on the effectiveness of the CBEA specification, and on whether Walmart wishes to continue using it at other sites. Walmart's adoption of the specification corporatewide would be a significant milestone that would encourage many others to follow suit. 


\subsection{GATEWAY Requirements}

The GATEWAY program has three goals for demonstrations: (1) saving energy, (2) matching or improving illumination, and (3) being cost-effective relative to the incumbent or other competing technology. The LED system by far uses the least energy of the three systems considered, though as discussed it also produces the lowest average illuminance. At the same time, the LED system produced slightly more uniform illumination, no small feat given that both the 400W and 1000W PMH systems are relatively uniform themselves.

The LED system matched the 400W system in terms of minimum illuminance, though neither system matched the minimum illuminance of $1.7 \mathrm{fc}$ that the $1000 \mathrm{~W}$ PMH system provides. However, this minimum illuminance value is 8.5 times greater than recommended in RP-20-98, while the maximum illuminance values of the $1000 \mathrm{~W}$ system are 41 times the recommended values. A significant energy savings can be accomplished by simply reducing the illumination requirements from the outset, as was done in this location, to more closely match IES recommendations. In lieu of high lighting levels, sites might consider alternatives, such as more reflective parking surfaces, use of contrast, and use of conspicuity to highlight elements, to increase perceived brightness.

The simple payback for this LED installation is 7.5 years when compared against the 1000W PMH system and 6.1 years when compared against the 400W PMH system. This may still be a longer payback than many retailers prefer, though as noted this site has atypically low electricity and labor costs. The LED system elements with the greatest influence on payback are the additional luminaires and poles needed to light the site.

The initial cost of the LED luminaires can be expected to continue to decrease, while luminaires with a greater lumen package and possibly different distributions may further reduce some of these initial costs. Over the 10-year analysis period, the LED system already achieves the lowest LCC of the three systems considered. 


\subsection{References}

ANSI/ASHRAE/IES Standard 90.1. Energy Standard for Buildings Except Low-Rise Residential Buildings. American Society of Heating, Refrigerating and Air-Conditioning Engineers, Atlanta, GA.

CBEA - U.S. Department of Energy Commercial Building Energy Alliance. 2010. CBEA LED Site Lighting Performance Specification, Version 1.2. Washington, DC. Accessed April 28, 2011 at http://apps1.eere.energy.gov/buildings/publications/pdfs/alliances/led_site_lighting_spec_06_09.pdf

CCR - California Code of Regulations, Title 24. California Building Standards Code. State of California Office of Administrative Law, Sacramento, CA.

EERE - U.S. Department of Energy, Office of Energy Efficiency and Renewable Energy. 2009. LED Site Lighting in the Commercial Building Sector: Opportunities, Challenges, and the CBEA Performance Specification. Available at http://www1.eere.energy.gov/buildings/ssl/led_site-lighting_webinar.html (last updated July 1, 2009).

EERE - U.S. Department of Energy, Office of Energy Efficiency and Renewable Energy. 2011. LED Site (Parking Lot) Lighting Technology Specification. Last accessed on April 15, 2011 at http://www1.eere.energy.gov/buildings/alliances/parking lot lighting.html (last updated March 10, 2011).

EIA - U.S. Department of Energy, Energy Information Administration. 2011. Average Retail Price of Electricity to Ultimate Customers by End-Use Sector, by State. Last accessed April 15, 2011 at http://www.eia.doe.gov/cneaf/electricity/epm/table5_6_a.html (undated webpage).

ICC - International Code Council. 2009. 2009 International Energy Conservation Code. Washington, D.C.

IES LM-79-08. Electrical and Photometric Measurements of Solid-State Lighting Products. Illuminating Engineering Society of North America, New York, NY.

IESNA DG-13-98. Selection of Photocontrols for Outdoor Lighting Applications. Illuminating Engineering Society of North America, New York, NY.

IESNA RP-20-98. Lighting for Parking Facilities. Illuminating Engineering Society of North America, New York, NY.

PCA - Portland Cement Association. 2005. Influence of Pavement Reflectance on Lighting for Parking Lots. Skokie, IL. 